\title{
Adsorption of copper, nickel and lead ions from synthetic semiconductor industrial wastewater by palm shell activated carbon
}

\author{
Y. B. Onundi; *A. A. Mamun; M. F. Al Khatib; Y. M. Ahmed \\ Bioenvironmental Engineering Research Unit (BERU), Department of Biotechnology Engineering, Faculty of \\ Engineering, International Islamic University Malaysia, Gombak, 50728 Kuala Lumpur, Malaysia \\ Received 10 May 2010; revised 26 June 2010; accepted 19 July 2010
}

\begin{abstract}
Granular activated carbon produced from palm kernel shell was used as adsorbent to remove copper, nickel and lead ions from a synthesized industrial wastewater.Laboratory experimental investigation was carried out to identify the effect of $\mathrm{pH}$ and contact time on adsorption of lead, copper and nickel from the mixed metals solution. Equilibrium adsorption experiments at ambient room temperature were carried out and fitted to Langmuir and Freundlich models. Results showed that pH 5 was the most suitable, while the maximum adsorbent capacity was at a dosage of 1 $\mathrm{g} / \mathrm{L}$, recording a sorption capacity of $1.337 \mathrm{mg} / \mathrm{g}$ for lead, $1.581 \mathrm{mg} / \mathrm{g}$ for copper and $0.130 \mathrm{mg} / \mathrm{g}$ for nickel. The percentage metal removal approached equilibrium within $30 \mathrm{~min}$ for lead, $75 \mathrm{~min}$ for copper and nickel, with lead recording $100 \%$, copper $97 \%$ and nickel $55 \%$ removal, having a trend of $\mathrm{Pb}^{2+}>\mathrm{Cu}^{2+}>\mathrm{Ni}^{2+}$. Langmuir model had higher $\mathrm{R}^{2}$ values of $0.977,0.817$ and 0.978 for copper, nickel and lead respectively, which fitted the equilibrium adsorption process more than Freundlich model for the three metals.
\end{abstract}

Keywords: Granular activated carbon; Heavy metals; Isotherm; Sorption; Wastewater

\section{INTRODUCTION}

High concentration of heavy metals in the environment can be detrimental to a variety of living species. Excessive ingestion of these metals by humans can cause accumulative poisoning, cancer, nervous system damage and ultimately death (Corpacioglu and Huang, 1987; Issabayeva et al., 2007). In Malaysia, industries dealing in electroplating, electronics, batteries and metal treatment/fabrication are the major sources of heavy metals contamination. Many of these industries are located in the western coast of the peninsular Malaysia, which includes Klang Valley, Malacca, Johor Bahru and Penang areas (DOE, 1979). Increased concern by environmentalists and governments on the effects of heavy metals and an attempt to protect public health has resulted in increased research in the development of advance technologies to remove heavy metals from waters and wastewaters (Bong et al., 2004; Karbassi et al., 2007; Shetty and Rajkumar, 2009; Resmi et al., 2010). Such treatment efforts involved application of unit operations or unit processes such as chemical precipitation, coagulation, adsorption, ion exchange

\*Corresponding Author Email: mamun@iium.edu.my Tel./Fax: +60123650516 and membrane filtration (Georg Steinhauser, 2008). Furthermore, among aforementioned treatment technologies, adsorption had been reported as an efficient and economic option (Skinner and Bassin, 1988; Mahvi, 2008; Malakootian et al., 2009). Anumber of adsorbent materials have been studied for their ability to remove heavy metals and they have been sourced from natural materials and biological wastes of industrial processes (Igbinosa and Okoh, 2009). These materials including: activated carbon (Uzun and Guzel, 2000; Goel et al., 2005; Issabayeva et al., 2007; Mondal et al., 2008), chitosan and carrageenan (Bong et al., 2004), lignite (Allen et al., 1997), kaolinite and ballclay (Chantawong et al., 2003), diatomite (Ulmanu et al., 2003), coconut fiber (Igwe et al. 2007) and limestone (Aziz et al., 2004). However, adsorption by activated carbon had been reported as a technically and economically viable technology for heavy metal removal (Huang and Morehart, 1991; Bong et al., 2004).

In Malaysia, the palm oil industry generates huge amounts of palm shell; a large portion of it is either burned in open air or dumped in area adjacent to the mill, which creates environmental and disposal problems. Therefore, application of palm shell activated 
carbon as an adsorbent offers highly effective technological means in dealing with pollution of heavy metals and solving palm shell disposal problems, with minimum investment required (Najua et al., 2008). Pervious works on metals removal had focused on single metal ions removal and little information is available on multimetal adsorption (Abdel-Ghani and Elchaghaby, 2007; Abdel-Ghani et al., 2009) even though most industries produce wastewater containing more than one metal ion in their effluent. In this work, investigation on the effect of $\mathrm{pH}$, contact time and dosage on metal adsorption from a matrix of 3 metals was carried out using palm shell based activated carbon. While isotherm studies were used to model the adsorption process.

\section{MATERIALS AND METHODS}

Industrial wastewater samples from a semiconductor company (located at Kuala Langat, Malaysia) were collected for a week (8-12, June 2009), preserved and tested for metals content following standard method (Standard Methods, 2000) procedures. The concentration of heavy metals, namely lead, nickel and copper in the industrial wastewater served as the bases for the adsorption study in the laboratory.

\section{Adsorbate}

Metals solutions (copper, lead and nickel) of 1000 $\mathrm{mg} / \mathrm{L}$ in nitric acid were purchased from Fisher Scientific, UK. Aqueous solutions of metals were prepared in the laboratory based on metal concentration in the industrial effluent. Each metal solution was diluted with distilled water to obtain the desired initial concentration, to mimic the industrial wastewater.

\section{Adsorbent}

The palm shell based granular activated carbon (GAC) was listed in Table 1 used as an adsorbent for this research was bought from KD Technology Malaysia. The adsorbent was washed with distilled water to remove fines and dirt following the procedure of Goel et al. (2005). The wet material was then dried at $110{ }^{\circ} \mathrm{C}$ for $6 \mathrm{~h}$ before characterization was done and used in the adsorption studies at ambient room temperature of $27^{\circ} \mathrm{C}( \pm 2)$.

\section{Adsorbent characterization}

Scanning electron microscope (SEM) (JSM-5600 model) machine of the Japanese manufacturer (JEOL Ltd.) was employed to check the surface morphology of
Table 1: Properties of GAC adsorbents

\begin{tabular}{ll}
\hline Parameters & GAC \\
\hline Raw material & Palm Kernel Shell \\
Particle size $(\mathrm{mm})$ & $1.68-2.38$ \\
Ash content & $4 \%$ max \\
Density $\left(\mathrm{g} / \mathrm{cm}^{3}\right)$ & 0.864 \\
Surface area $\left(\mathrm{m}^{2} / \mathrm{g}\right)(\mathrm{BET})$ & 513.3 \\
Average pore size $(\AA)$ & 48.5 \\
Total pore volume $(\mathrm{cc} / \mathrm{g})$ & 0.622 \\
Elemental analysis $(\%)$ & \\
$\mathrm{C}$ & 64.45 \\
$\mathrm{~N}$ & 23.09 \\
$\mathrm{O}$ & 0.00 \\
Others & 32.09 \\
\hline
\end{tabular}

the GAC. The same machine was also used for the energy dispersive $\mathrm{x}$-ray (EDX) spectra analysis to know the elemental composition of the GAC. Adsorbent samples for Fourier transform infrared (FTIR) analysis were prepared by diluting the GAC to $5 \%$ in $\mathrm{KBr}$ and cast in disks for analysis to obtain the spectrum from a PerkinElmer precisely of model 100, earlier followed by Zvinowanda et al., (2009). Specific surface area of the GAC was measured by an American Coulter sorptometer machine of model SA-3100, using $\mathrm{N}_{2}$ as adsorbent at the liquid nitrogen temperature of $-196^{\circ} \mathrm{C}$.

\section{Adsorption study}

For each experiment, 50 mLof synthetic water sample containing mixed metals of $2.0 \mathrm{mg} / \mathrm{L} \mathrm{Cu}, 1.5 \mathrm{mg} / \mathrm{L} \mathrm{Pb}$ and $0.8 \mathrm{mg} / \mathrm{L} \mathrm{Ni}$, was prepared based on industrial wastewater metal concentration and added to a calculated amount of adsorbent in $100 \mathrm{~mL}$ shake flask. The $\mathrm{pH}$ adjustment of solution was done using $1.0 \mathrm{M}$ HCL and 1.0 M NaOH. The adsorbent in solution was agitated in a mechanical shaker at a speed of $100 \mathrm{rpm}$ at $27{ }^{\circ} \mathrm{C}( \pm 2)$. Blank solutions were treated similarly without the adsorbent and under control condition. The solution was filtered using a Whatman ${ }^{\circledR} 0.45 \mu \mathrm{m}$ filter paper. The results were analyzed for the residual concentration of metals in the filtrate by atomic adsorption spectrophotometer (PerkinElmer HGA900).

Equilibrium concentration of metals at different adsorbent dosage (1, 2, 3, $4 \mathrm{~g} / \mathrm{L}$ ), at ambient temperature was used for the isotherm study. The adsorption capacity of adsorbent was calculated using Eq.1.

$q_{t}=\frac{\left(C_{0}-C_{t}\right) \cdot V}{m}$

Where, $q_{t}$ is the adsorption capacity of the adsorbent at time $\mathrm{t}$ (mg adsorbate/g adsorbent); $\mathrm{C}_{0}$ is 
the initial concentration of metal $(\mathrm{mg} / \mathrm{L})$; $\mathrm{C}_{\mathrm{t}}$ is the residual concentration of metal after adsorption had taken place over a period of time $\mathrm{t}(\mathrm{mg} / \mathrm{L})$; $\mathrm{V}$ is volume of metal solution in shake flask (L) and $\mathrm{m}$ is mass of adsorbent (g) (Metcalf and Eddy, 2003). The metal removal percentage (R \%) was calculated using Eq. 2.

$R(\%)=\frac{\left(C_{0}-C_{t}\right) \cdot 100}{C_{0}}$

Where ( $\mathrm{R} \%)$ is the ratio of difference in metal concentration before and after adsorption.

\section{RESULTS AND DISCUSSION}

Physical and chemical characterization of adsorbent

The SEM image of Fig. 1 reveals the porous structure of the GAC surfac. The FTIR spectra of GAC are shown in Fig. 2, whilea summary of the peaks and their assignment are in Table 2. As can be inferred from the FTIR analysis, the acidic functional groups present on GAC surface were: carboxyl, carbonyl, lactones and sulphur groups. These groups had been reported to enhance metals adsorption (Zhang et al., 2009; Edwin, 2008; Goel et al., 2005). Specifically sulphur groups were reported by Goel et al, (2005) as aiding lead ions adsorption.

\section{Effect of $\mathrm{pH}$ on adsorption}

The uptake and percentage removal of metals from the aqueous solution are strongly affected by the $\mathrm{pH}$ of the solution (Horsfall and Abia, 2003; Zvinowanda et al. 2009). Fig. 3 shows the effect of $\mathrm{pH}$ variation on adsorption of copper, nickel and lead ions on GAC surface. The uptake of $\mathrm{Cu}, \mathrm{Ni}$ and $\mathrm{Pb}$ increased from $0.095 \mathrm{mg} / \mathrm{g}$ to $0.685 \mathrm{mg} / \mathrm{g} ; 0.045 \mathrm{mg} / \mathrm{g}$ to $0.137 \mathrm{mg} / \mathrm{g}$ and

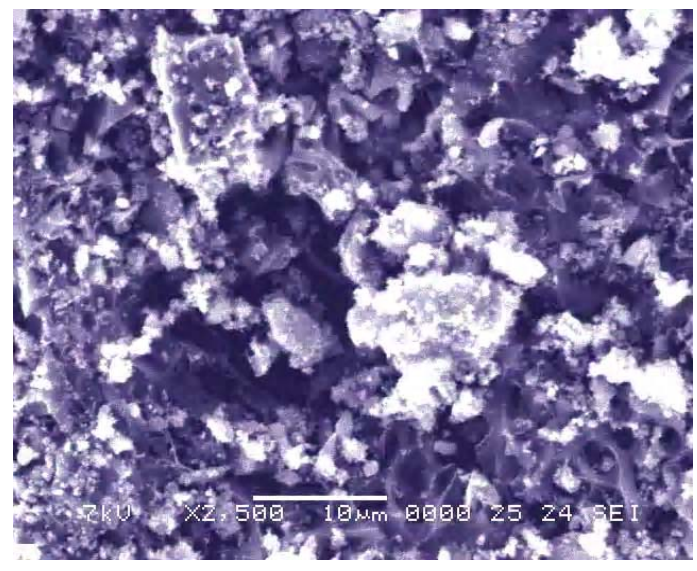

Fig. 1: SEM image of GAC surface

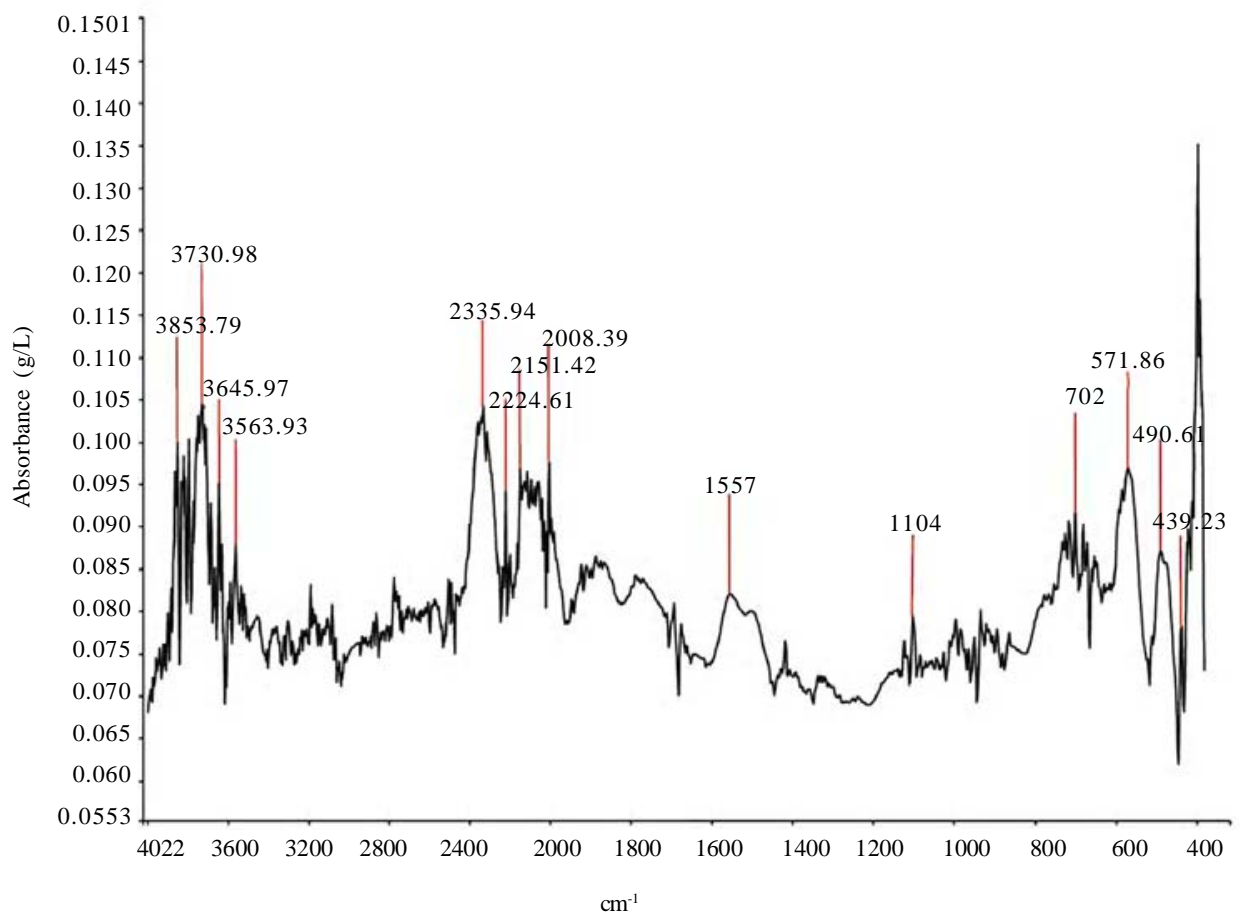

Fig. 2: FTIR spectrum of GAC 
$0.111 \mathrm{mg} / \mathrm{g}$ to $0.493 \mathrm{mg} / \mathrm{g}$, respectively when the solution's $\mathrm{pH}$ was increased from 2 to 5 . For $\mathrm{pH}$ values above 5, the adsorption capacity decreased with increment in $\mathrm{pH}$. The mechanism of metals adsorption by the adsorbent with $\mathrm{pH}$ variation could be explained with the same concept as put forward by Corapcioglu and Huang (1987), Bansal and Goyal (2005), Najua et al. (2008) and that in the $\mathrm{pH}$ range of 2 to 3, copper, lead and nickel ions would be present predominately as M(II) ions. The minimum adsorption observed at low $\mathrm{pH}$ of 2 could be, on one hand due to the fact that the presence of higher concentration and higher mobility of $\mathrm{H}^{+}$ions favoured $\mathrm{H}^{+}$adsorption compared to $\mathrm{M}$ (II) ions and on the other hand due to the high solubility and ionization of metals salt in the acidic medium. It would be plausible to suggest that at lower $\mathrm{pH}$ value, the surface of the adsorbent is surrounded by hydronium ions $\left(\mathrm{H}^{+}\right)$, thereby preventing metals ions from approaching the binding sites of the adsorbents. At higher $\mathrm{H}^{+}$concentration, the adsorbents surface becomes more positively charged such that the attraction between adsorbents and metal cations is reduced. In contrast, as the $\mathrm{pH}$ increases, more negatively charged surface becomes available thus facilitating greater metals removal. It could be deduced that the sorption of metal cations increased with increasing $\mathrm{pH}$ as the metal ionic species become less stable in the solution. The maximum adsorption observed in the $\mathrm{pH}$ range of 4.5 to 6 might be due to partial hydrolysis of metal ions, resulting in the formation of $\mathrm{M}(\mathrm{OH})^{+}$ions and $\mathrm{M}(\mathrm{OH})^{2}$, which would be adsorbed to a greater extent on a less-polar carbon surface of the adsorbents compared to $\mathrm{M}^{2+}$ ions.
Furthermore, the low solubility of hydrolyzed metal species may be another reason for maximum adsorption in this $\mathrm{pH}$ range.

\section{Effect of contact time}

The relationship of percentage metals removal by adsorbent with contact time was plotted and presented in Fig. 4. The amount of the adsorbed metal ions increased as the time lapses, similar case was recorded by Gueu, et al., (2007). The adsorbent showed a rapid metal reduction for the first 5 min of contact time, with further increase in time the sorption kinetics decreased progressively. The percentage metal removal approached equilibrium within 30 min for $\mathrm{Pb}$ and 75 min for $\mathrm{Cu}$ and $\mathrm{Ni}$. The fast adsorption at the initial stage was probably due to the initial concentration gradient between the adsorbate in solution and the number of vacant sites available on the GAC surface at the beginning. The progressive increase in adsorption and consequently the attainment of equilibrium adsorption may be due to limited mass transfer of the adsorbate molecules from the bulk liquid to the external surface of GAC. It was noted that the sorption capacities

Table 2: Peaks from GAC spectrum and their possible assignment

\begin{tabular}{ll}
\hline $\begin{array}{l}\text { GAC Band } \\
\text { position/cm }\end{array}$ & \multicolumn{1}{c}{ Possible assignments } \\
\hline 3564 & O-H stretching (intermolecular diametric) \\
$3200-2800$ & C-H stretching (alkenes) \\
2151 & C=N stretching (alkynes) \\
1697 & C=O Stretching (aldehydic) \\
1104 & S-O Stretching (sulfates) \\
1125 & C-H Amines \\
$680-610$ & S-O Bends (sulfates) \\
\hline
\end{tabular}

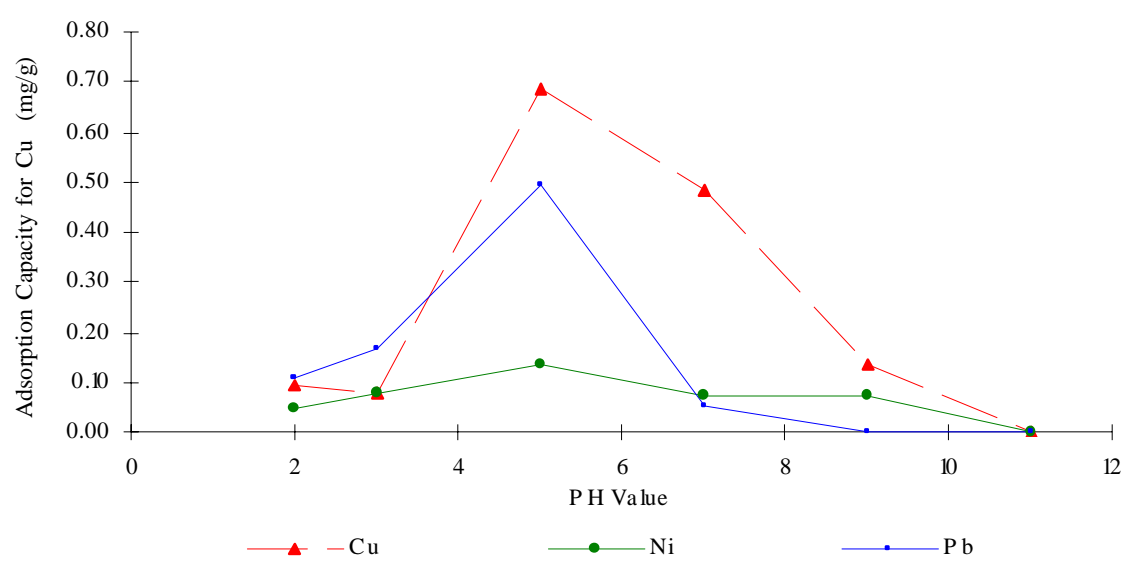

Fig. 3: Effect of $\mathrm{pH}$ on adsorption of metals onto GAC from a mixed metals solution 
corresponding to equilibrium varied for each metal, with lead recording $100 \%$, copper $97 \%$ and nickel $55 \%$, giving a trend of $\mathrm{Pb}>\mathrm{Cu}>\mathrm{Ni}$ on the adsorbent. It was assumed that the acidic groups on the GAC had affinity for the three metals; the observed trend was probably due to the sulphate group on the adsorbent having higher affinity for lead ions, making lead reach equilibrium concentrations faster than copper and nickel ions. The higher initial concentration of copper also favored copper over nickel in the percent uptake achieved by 75 $\mathrm{min}$. It is plausible to assume that the lower concentration of nickel probably did not favor nickel competition with lead and copper for the same available adsorption site on the GAC surface, which resulted in the comparable lower amount of nickel removal before equilibrium was attained.

\section{Effect of adsorbent dosage}

The effect of variation of GAC dosage on amount of metal adsorbed is shown in Fig. 5. A trend of increment in adsorption capacity with increment in adsorbent dosage was observed from $0.5 \mathrm{~g} / \mathrm{L}$ to $1 \mathrm{~g} / \mathrm{L}$. Adsorbent recorded a maximum capacity of $1.581 \mathrm{mg} / \mathrm{g}$ for copper, $1.337 \mathrm{mg} / \mathrm{g}$ for lead and $0.130 \mathrm{mg} / \mathrm{g}$ for nickel at $1 \mathrm{~g} / \mathrm{L}$ dosage. Further increment of adsorbent above $1 \mathrm{~g} / \mathrm{L}$ resulted in a decline in adsorption capacity.The initial increment in adsorption capacity with increase in adsorbent dosage was expected, since number of adsorbent particles increases and thus more surface areas were available for metals attachment. Same trend was reported by Dakiky et al. (2002), Acharya et al., (2009).

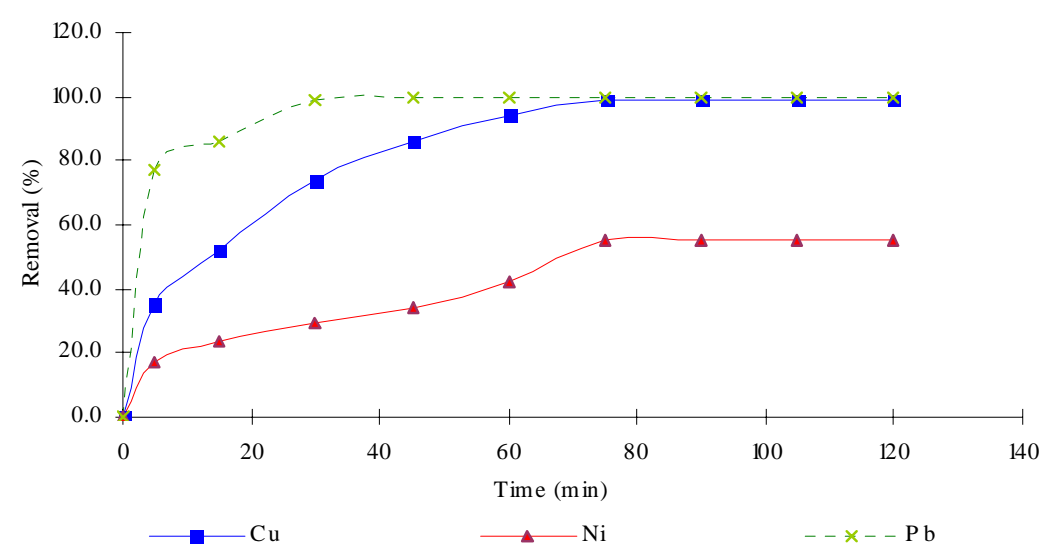

Fig. 4: Effect of contact time on adsorption of $\mathrm{Cu}$ (II), Ni (II) and $\mathrm{Pb}$ (II) (at ambient temperature $=27( \pm 2)^{\circ} \mathrm{C}$, adsorbent dose $=4 \mathrm{~g} / \mathrm{L}, \mathrm{pH}=5$ ).

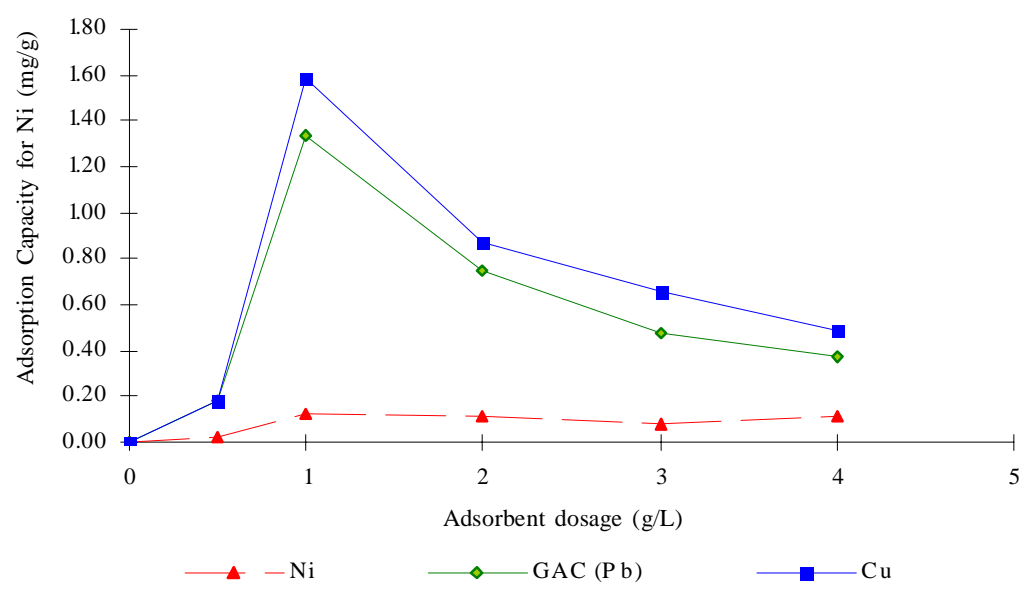

Fig. 5: Effect of adsorbent dosage (g) variation on metals adsorption (at pH5, agitation period of $75 \mathrm{~min}$ at $100 \mathrm{rpm}$ ) 
It is plausible to suggest that with higher dosage of adsorbent there would be greater availability of exchangeable sites for metal ions as noted by Babel and Kurniawan (2004) and Najua et al. (2008). Further increment in adsorbent dosage beyond maximum adsorption capacity at $1 \mathrm{~g} / \mathrm{L}$ resulted in a decline in capacity as shown in Fig. 5. This reduction in capacity had been explained as due to the overlapping of the adsorption sites as a result of overcrowding of adsorbent particles beyond $1 \mathrm{~g} / \mathrm{L}$ dose (Garg et al., 2003; Najua et al., 2008). Moreover, the high adsorbent dosage could impose a screening effect on the dense outer layer of the cells, thereby shielding the binding sites from metals (Pons and Fuste, 1993).

\section{Equilibrium adsorption isotherms}

Several models had been used in literatures to describe the experimental data of adsorption isotherms. The Freundlich (Freundlich and Hatfield, 1926) and Langmuir (Langmuir, 1918) models are the most frequently employed models, these two models were used in the present work. Equilibrium data obtained were fitted to the Langmuir and Freundlich isotherms. The following expressions of straight line were found by means of mathematical transformation of isotherms equation. Langmuir isotherm is shown as Eq.3:

$c_{s}=\frac{1}{x / m}=\frac{1+b c_{e}}{a b c_{e}}=\frac{1}{a}+\frac{1}{a b c_{e}}$

Freundlich isotherm is shown as Eq. 4:

$\log \left(\frac{x}{m}\right)=\log K_{f}+\frac{1}{n} \log C_{e}$

Where, $\mathrm{C}_{\mathrm{s}}$ is the amount of contaminant sorbed on the solid per unit of solid (mg sorbate/g sorbent), $\mathrm{C}_{\mathrm{e}}$ is the concentration of contaminant remaining in solution at equilibrium $(\mathrm{g} / \mathrm{L})$; $\mathrm{x}$ is the mass of contaminant adsorbed (g); $\mathrm{m}$ is the mass of solid sorbent (g) a and $\mathrm{n}$ are empirical coefficients; a $(\mathrm{mg} / \mathrm{g})$ in the Langmuir equation is indicative of the relative adsorption capacity of the adsorbent. The constant $b$ is the saturation coefficient $\left(\mathrm{m}^{3} / \mathrm{g}\right)$ and $\mathrm{K}_{\mathrm{f}}$ is the Freundlich constant indicative of the relative adsorption capacity of the adsorbent $(\mathrm{mg} /$ g). The constant $1 / \mathrm{n}$ indicates the tendency of the adsorbate to be adsorbed (Bishop, 2004; Goel et al., 2005). The estimated model parameters with correlation coefficient $\left(\mathrm{R}^{2}\right)$ for the two models are shown in Table 3. It was observed that results fitted better in the Langmuir model in terms of $\mathrm{R}^{2}$ value, recording 0.978 for lead, 0.977 for copper and 0.817 for nickel. The affinity of the metals for the adsorbent surface in terms of value " $b$ " in the Table 3 varied in the trend $\mathrm{Pb}>\mathrm{Cu}>\mathrm{Ni}$, which is in agreement with the trend in Fig. 4. It was assumed that this trend was due to the presence of sulphate acidic group present on the GAC surface. It was observed that the trend of adsorption capacity in terms of constant "a" was $\mathrm{Cu}$ $>\mathrm{Pb}>\mathrm{Ni}$. This was probably due to the initial concentration of metals following same trend and this trend is inline with trend in Figs. 3 and 4. It could be inferred from this result that the trend of constant "b" was due to sulphate group present on the GAC, it also made $\mathrm{Pb}$ have higher affinity for the GAC surface, making it reach equilibrium concentration within 30 min of contact time, while $\mathrm{Cu}$ and $\mathrm{Ni}$ took longer time as was observed in Fig. 4. However, the higher initial concentration of copper favored copper in total metal adsorbed on the GAC as shown in the trend of Fig. 5, which also explains the trend of constant "a" in Table 3.

Table 3: Isotherm parameters for metals adsorption at $27( \pm 2){ }^{\circ} \mathrm{C}$ and pH 5

\begin{tabular}{|c|c|c|c|c|c|}
\hline Metals & Equation & & & Cs (Equation) & $\mathrm{R}^{2}$ \\
\hline \multirow{2}{*}{ Copper } & Langmuir & $\mathrm{a}=1.263$ & $b=57.519$ & $c_{s}=\frac{x}{m}=\frac{(1.263)(57.519)}{1+57.519 C_{e}}$ & 0.977 \\
\hline & Freundlich & $\mathrm{Kf}=0.228$ & $\mathrm{n}=3.777$ & $C_{s}=\frac{X}{m}=0.228 . c_{e}^{1 / 3.777}$ & 0.581 \\
\hline \multirow{2}{*}{ Nickel } & Langmuir & $\mathrm{a}=0.261$ & $\mathrm{~b}=2.2951$ & $C_{s}=\frac{x}{m}=\frac{(0.261)(2.2951)}{1-2.2951 C_{e}}$ & 0.817 \\
\hline & Freundlich & $\mathrm{Kf}=-0.607$ & $\mathrm{n}=1.29927$ & $c_{s}=\frac{X}{m}=-0.607 \cdot c_{e}^{1 / 1.29927}$ & 0.761 \\
\hline \multirow{2}{*}{ Lead } & Langmuir & $a=0.841$ & $b=80389.61$ & $c_{s}=\frac{x}{m}=\frac{(0841)(80389.61)}{1+80389.61 C_{e}}$ & 0.978 \\
\hline & Freundlich & $\mathrm{Kf}=0.112$ & $\mathrm{n}=8.4295$ & $c_{s}=\frac{X}{m}=0.112 \cdot c_{e}^{1 / 8.4295}$ & 0.709 \\
\hline
\end{tabular}




\section{CONCLUSION}

It was observed that copper, nickel and lead ions adsorption by GAC had highest adsorption capacity at $\mathrm{pH}$, while the maximum adsorbent dosage was $1 \mathrm{~g} / \mathrm{L}$ recording a sorption capacity of $1.337 \mathrm{mg} / \mathrm{g}$ for lead, $1.581 \mathrm{mg} / \mathrm{g}$ for copper and 0.130 for nickel. The metal removal approached equilibrium within $30 \mathrm{~min}$ for $\mathrm{Pb}, 75 \mathrm{~min}$ for $\mathrm{Cu}$ and $\mathrm{Ni}$ of contact time. Langmuir model having higher $\mathrm{R}^{2}$ values of $0.977,0.817$ and 0.978 for copper, nickel and lead respectively fitted the equilibrium adsorption data more than the Freundlich model for the three metals. From the isotherm constants, it was observed that the trend of metals affinity for GAC surface was $\mathrm{Pb}>\mathrm{Cu}>\mathrm{Ni}$, while the adsorbent metals affinity followed the trend $\mathrm{Cu}>\mathrm{Pb}>$ $\mathrm{Ni}$. This observed difference was assumed to be due to the sulphate functional groups present on GAC having higher affinity for $\mathrm{Pb}$ ions, while initial metal concentration favored $\mathrm{Cu}$ adsorption.

\section{ACKNOWLEDGMENTS}

The authors wish to acknowledge the Endowment Fund Type A of International Islamic University (IIUM) for funding the research. Assistance from all members of Nanoscience and Nanotechnology Research Group (NANORG) and Bio-environmental Research Unit (BERU) of the Faculty of Engineering IIUM is very much appreciated.

\section{REFERENCES}

Abdel Ghani, N.; Elchaghaby, G. A., (2007). Influence of operating conditions on the removal of $\mathrm{Cu}, \mathrm{Zn}, \mathrm{Cd}$ and $\mathrm{Pb}$ ions from wastewater by adsorption., Int. J. Environ. Sci. Tech., 4 (4), 451-456 (6 pages).

Abdel-Ghani, N. T.; Hegazy, A. K.; El-Chaghaby, G. A., (2009). Typha domingensis leaf powder for decontamination of aluminium, iron, zinc and lead: Biosorption kinetics and equilibrium modeling. Int. J. Environ. Sci. Tech., 6 (2), 243248 (6 pages).

Acharya, J.; Sahu, J. N.; Mohanty, C. R.; Meikap, B. C., (2009). Removal of lead (II) from wastewater by activated carbon developed from Tamarind wood by zinc chloride activation. Chem. Eng. J., 149 (1-3), 249-262 (14 pages).

Allen, S.J.; Whitten, L. J.; Murray, M. and Duggan, O., (1997). The adsorption of pollutants by mpeat, lignite and activated chars. J. Chem. Tech. Biotech., 68 (4), 442-452 (11 pages).

Aziz, H. A.; Yusoff, M. S.; Adlan, M. N.; Adnan, N. H.; Alias, S., (2004). Physico-chemical removal of iron from semiaerobic landfill leachate by limestone filter. Waste Manag., 24 (4), 353-358 (6 pages).

Babel, S.; Kurniawan, T. A., (2004). Cr (VI) removal from synthetic wastewater using coconut shell charcoal and commercial activated carbon modified with oxidizing agents and/or chitosan. Chemosphere, 54 (7), 951-967 (17 pages).
Bansal, R. C.; Goyal, M., (2005). Activated carbon adsorption. London, Taylor and Francis Group, 351-353.

Bishop, P.L. (2004). Pollution prevention: Fundamentals and practice, Waveland Press Inc.

Bong, K. P.; Seung, H. S.; Young, J. Y., (2004). Selective biosorption of mixed heavy metal ions using polysaccharides. Korean J. Chem. Eng., 21 (6), 1168-1172 (5 pages).

Chantawong, V.; Harvey, N. W.; Bashkin, V. N., (2003). Comparison of heavy metals adsorption by Thai Kaolin and Ballclay. Water, Air, Soil Pollut., 148 (1-4), 111-125 (15 pages).

Corapcioglu, M. O.; Huang, C. P., (1987). The adsorption of heavy metals onto hydrous activated carbon. Water Res., 21 (9), 1031-1044 (14 pages).

Dakiky, M.; Khamis, M.; Manassra, A.; Mer'eb, M., (2002). Selective adsorption of chromium (VI) in industrial wastewater using low-cost abundantly available adsorbents. Adv. Environ. Res., 6 (4), 533-540 (8 pages).

Department of Environment-DOE (1979)., Environmental Quality (Sewage and industrial effluents) Regulations 1978, In: Environmental Quality Act 1974. E-publishing Lawnet, Malaysia.

Edwin, V. A., (2008). Surface Modification of Activated Carbon for enhancement of Nickel (II) adsorption. E-J. Chem., 5(4), 814-819 (6 pages).

Freundlich, H.; Hatfield, H., (1926). Colloid and Capillary Chemistry. Methuen and Co. Ltd., London.

Garg, V.K.; Gupta, R.; Yadav, A. B.; Kumar, R. D., (2003). Dye removal from aqueous solution by adsorption on treated sawdust. Bioresour. Tech., 89 (2), 121-124 (4 pages).

Georg Steinhauser, M. B., (2008). Adsorption of ions onto high silica volcanic glass. Appl. Rad. Iso., 66 (1), 1-8 (8 pages).

Goel, J.; Krishna, K.; Chira, R.; Vinod, K., (2005). Removal of lead (II) by adsorption using treated granular activated carbon and column studies. J. Hazard. Mater., B125, 211-220 (10 pages).

Gueu, S.; Yao, B.; Adouby, K.; Ado, G., (2007). Kinetics and thermodynamics study of lead adsorption on to activated carbons from coconut and seed hull of the palm tree. Int. J. Environ. Sci. Tech., 4 (1), 11-17 (7 pages).

Horsfall, M.; Abia, A., (2003) . Sorption of C(II) and Zn(II) ions from aqueous solutions by cassava waste biomass. Water Res., 37 (20), 4913-4923 (11 pages).

Huang, C. P.; Morehart, A. L., (1991). Proton competition in $\mathrm{Cu}(\mathrm{II})$ adsorption in fungal Mycellia. Water Res., 25 (11), 1365-1375 (11 pages).

Igbinosa, E. O.; Okoh, A. I., (2009). Impact of discharge wastewater effluents on the physico-chemical qualities of a receiving watershed in a typical rural community. Int. J. Environ. Sci. Tech., 6 (2), 175-182 (8 pages).

Igwe, J. C.; Abia, A. A.; Ibeh, C. A., (2007). Adsorption kinetic and intraparticulate diffusivities of $\mathrm{Hg}$, $\mathrm{As}$ and $\mathrm{Pb}$ ions on unmodified and thiolated coconut fiber. Int. J. Environ. Sci. Tech., 5 (1), 83-92 (10 pages).

Issabayeva, G.; Aroua, M. K.; Sulaiman, N. M., (2007). Continuous adsorption of lead ions in a column packed with palm shell activated carbon. J. Hazard. Mater., 155 (1-2), 109-113 (5 pages).

Karbassi, A. R.; Nouri, J.; Ayaz, G. O., (2007). Flocculation of trace metals during mixing of Talar river water with Caspian Seawater. Int. J. Environ. Res., 1 (1), 66-73 (8 pages). 
Langmuir, I., (1918). The adsorption of gases on plane surfaces of glass, mica and platinum. J. Am. Chem. Soc., 40 (8), 1361-1403 (43 pages).

Mahvi, A.H., (2008). Application of agricutural fibers in pollution removal from aqueous solution. Int. J. Environ. Sci. Tech., 5 (2), 275-285 (11 pages).

Malakootian, M.; Almasi, A.; Hossaini, H., (2009). Pb and Co removal from paint industries effluent using wood ash. Int. J. Environ. Sci. Tech., 5 (2), 217-222 (6 pages).

Metcalf and Eddy (2003). Wastewater Engineering: Treatment and Reuse. In: McGraw Hill series in civil and environmental engineering, $4^{\text {th. }}$ Ed. (pp. 1149 and 1819)., McGraw-Hill, New York.

Mondal, P.; Majumder C. B.; Mohanty, B. ( 2008). Effects of adsorbent dose, its particle size and initial arsenic concentration on the removal of arsenic, iron and manganese from simulated ground water by $\mathrm{Fe}^{3+}$ impregnated activated carbon. J. Hazard. Mater., 150 (3), 695-702 (8 pages).

Najua, D. T.; Luqman, C. A.; Zawani, Z.; Suraya, A. R. (2008). Adsorption of copper from aqueous solution by Elais Guineensis kernel activated carbon., J. Eng. Sci. Tech., 3 (2), 180-189 (10 pages).

Pons, M. P.; Fuste, C. M., (1993). Uranium uptake by immobilized cells of Pseudomonas strain EPS 5028. Appl. Microbio. Biotech., 39 (4-5), 661-665 (5 pages).

Resmi, G.; Thampi, S. G.; Chandrakaran, S., (2010). Brevundimonas vesicularis check for this species in other resources: A novel bio-sorbent for removal of lead from wastewater. Int. J. Environ. Res., 4 (2), 281-288 (7 pages). Shetty, R.; Rajkumar, Sh., (2009). Biosorption of Cu (II) by metal resistant Pseudomonas check for this species in other resources sp. Int. J. Environ. Res., 3 (1), 121-128 (8 pages).

Skinner, J. H.; Bassin, N. J. (1988). The environmental protection agency's hazardouswaste research and development program., J. APCA.

Standard Methods (2000). Standard Methods for the Examination of Water and Wastewater, In: Metals, 3500.

Ulmanu, M.; Maranon, E.; Fernandez, Y.; Castrillon, L.; Anger, L.; Dumitriu, D., (2003). Removal of copper and cadmium ions from diluted aqueous solutions by low cost and waste material adsorbents. Water, Air, Soil Pollut., 142 (1-4), 357373 (17 pages).

Uzun, I.; Guzel, F. (2000). Adsorption of some heavy metal ions from aqueous solution by activated carbon and comparison of percentage adsorption results of activated carbon with those of some other adsorbents. Turk. J. Chem. 24, 291-297 (7 pages).

Zhang, J.; Huang, Z.; Ruitao, L.; Yang, Q. and Kang, F., (2009). Effect of growing CNTs onto Bamboo charcoals on adsorption of copper ions in aqueous solution. Langmuir, 25 (1), 269-274 (6 pages).

Zvinowanda, C. M.; Okonkwo, J. O.; Shabalala, P. N.; Agyei, N. M., (2009). A novel adsorbent for heavy metal remediation in aqueous environments. Int. J. Environ. Sci. Tech., 6 (3), 425-434 (10 pages).

\section{AUTHOR (S) BIOSKETCHES}

Onundi, Y. B., M.Sc., Department of Biotechnology Engineering, International Islamic University Malaysia, P.O.Box 10, 50728 Kuala Lumpur, Malaysia., Kuala Lumpur, Malaysia. Email: onudy1759@gmail.com

Mamun, A. A., Ph.D., Department of Biotechnology, Faculty of Engineering, International Islamic University Malaysia (IIUM), Jalan Gombak, 53100 Kuala Lumpur, Malaysia, Kuala Lumpur, Malaysia. Email: mamun@iium.edu.my

Al Khatib, M. F., Ph.D., Department of Biotechnology, Faculty of Engineering, International Islamic University Malaysia (IIUM), Jalan Gombak, 53100 Kuala Lumpur, Malaysia, Kuala Lumpur, Malaysia. Email: maan@iiu.edu.my

Ahmed, Y. M., M.Sc., Department of Biotechnology, Faculty of Engineering, International Islamic University Malaysia (IIUM), Jalan Gombak, 53100 Kuala Lumpur, Malaysia, Kuala Lumpur, Malaysia. Email: yahya1963@yahoo.com

\section{How to cite this article: (Harvard style)}

Onundi, Y. B.; Mamun, A. A.; Al Khatib, M. F.; Ahmed, Y. M., (2010). Adsorption of copper, nickel and lead ions from synthetic semiconductor industrial wastewater by palm shell activated carbon. Int. J. Environ. Sci. Tech., 7 (4), 751-758. 